\title{
Could meditation make part of psychiatric treatment?
}

\author{
Poderia a meditação fazer parte do tratamento psiquiátrico? \\ ¿Podría la meditación formar parte del tratamiento psiquiátrico?
}

Received: 07/06/2021 | Reviewed: 07/15/2021 | Accept: 07/16/2021 | Published: 07/25/2021

\author{
Maria Tereza Gonçalves-Mendes \\ ORCID: https://orcid.org/0000-0002-3037-7461 \\ Federal University of Alfenas, Brazil \\ E-mail: mtgves@gmail.com \\ Bruno Pinheiro Cambiaghi \\ ORCID: https://orcid.org/0000-0001-6714-8550 \\ Federal University of Alfenas, Brazil \\ E-mail: brunopcambiaghi@gmail.com \\ Tales Alexandre Aversi-Ferreira \\ ORCID: https://orcid.org/0000-0002-4417-7209 \\ Federal University of Alfenas, Brazil \\ E-mail: tales.ferreira@unifal-mg.edu.br
}

\begin{abstract}
This is an integrative review relating the effects of meditation in the brain and its possible use as preventive alternative medicine and an adjuvant in the psychiatric treatment. Studies have associated meditation and spirituality with increased life quality for being linked to emotional control and self-preservation behaviors, such as ethical practices, emotional regulation, attention improvement, stress and anxiety reduction and cognitive functions improvement in a general fashion, which is also evidenced by studies that analyzed morphological changes in correlated brain areas. This work proposes an integrative review in order to prove the hypothesis that meditation could be used as a practice in alternative and preventive medicine aiming to diminish the harmful effects of diseases and psychopathologies in general.
\end{abstract}

Keywords: Meditation; Spirituality; Life quality; Mental illness; Psychiatry.

\section{Resumo}

Este é um trabalho acerca dos efeitos da meditação no cérebro e seu possível uso como medicina alternativa preventiva e adjuvante no tratamento psiquiátrico. Estudos têm associado a meditação e a espiritualidade com o aumento da qualidade de vida por estarem associados a comportamentos de controle emocional e autopreservação, tais como práticas éticas, regulação emocional, melhora da atenção, diminuição de estresse e ansiedade e melhora de funções cognitivas de uma maneira geral, algo também evidenciado por estudos que analisam alterações morfológicas em áreas correlatas no cérebro. Este trabalho propõe uma revisão integrativa para provar a hipótese do uso da meditação como prática na medicina preventiva e alternativa a fim de atenuar os efeitos nocivos de doenças e de psicopatologias no geral.

Palavras-chave: Meditação; Espiritualidade; Qualidade de vida; Doenças mentais; Psiquiatria.

\section{Resumen}

Se trata de un trabajo acerca de los efectos de la meditación en el cerebro y su posible uso como medicina alternativa preventiva y adyuvante en el tratamiento psiquiátrico. Los estudios han asociado la práctica de meditación y la espiritualidad con una mayor calidad de vida, ya que están asociadas con conductas de control emocional y auto conservación, como prácticas éticas, regulación emocional, mejor atención, reducción del estrés y la ansiedad, y mejores funciones cognitivas en general, algo también evidenciado por estudios que analizan cambios morfológicos en áreas relacionadas en el cerebro. Este trabajo propone una revisión integradora para comprobar la hipótesis del uso de la meditación como práctica en la medicina preventiva y alternativa con el fin de mitigar los efectos nocivos de enfermedades y psicopatologías en general.

Palabras clave: Meditación; Espiritualidad; Calidad de vida; Enfermedad mental; Psiquiatría.

\section{Introduction}

The idea of spirituality can be associated directly with quality of life (Comstock \& Partridge, 1972; Levin \& Vanderpool, 1987; O’Regan \& Hirshberg, 1993; Levin, 2003; Stroppa \& Moreira-Almeida, 2008; Rocha \& Fleck, 2011; Barricelli et al., 2012; Melo et al., 2015), putatively because of the behaviour generated by religiosity/spirituality in people, such as abstaining from drinking, other moral and ethical practices, emotional and physical well-being (Rocha \& Fleck, 2004), offering a net of 
social support, nutrition, financial help (Ellison \& George, 1994) and an explanation about suffering, as well as motives generating faith and hope (Bowker, 1975) that can reduce the effects of diseases and harm from mental illness (Idler, 1987).

Indeed, studies indicate that prayer increases happiness and health (Ellison and Taylor, 1996), and generates calm and satisfaction (Koenig, Kvale \& Ferrel, 1988; Benor, 1992), alongside yoga and meditation (Funderburk, 1977).

The concepts of religiosity and spirituality present differences (Angerami-Camon, 2008; Murakami \& Campos, 2012; Paiva, 2001) that are important to separate for the purpose of this work.

Spirituality is associated with a deep feeling in life, a search for a life purpose but not necessarily associated with beliefs. When religiosity is associated with beliefs and practices in a doctrine, this can be shared by a group where there is a kind of faith (Murakami \& Campos, 2012).

In addition to these concepts, the practice of meditation is linked to spirituality mainly and the scope of life quality, and could be a good alternative method for preventive medicine, since meditation is related to a group of complex emotional and attentional practices (Kang et al., 2013), projecting a self-regulation of body and mind (Boccia, Piccardi \& Guariglia, 2015), or even body control because meditators show high tolerance for pain (Grant \& Rainville, 2009; Zeidan et al., 2012). Meditation could be used for the clinical treatment of pain (Zeidan et al., 2012), therefore relating the benefits of spirituality and meditation, which are close in terms of concepts and health improvement.

It seems that meditation really helps the amelioration of some behaviour according to many studies, for instance, improving memory, attention (Jha et al., 2010), abilities of perceptions (Maclean et al., 2010), better social behaviour (Condon et al., 2013) and emotional control (Hölzel et al., 2007); and several other researches have associated the brain's cortical alterations (Fox et al., 2014), of experienced meditators rather than novice ones (Kang et al., 2013), with neuroplasticity linked to neuron preservation and neurogenesis (Boccia, Piccardi \& Guariglia, 2015), as well as regulating the glucocorticoids, inflammation and serotonin metabolism (Larouche, Hudson \& Goulet, 2015), improving immunity (Davidson et al., 2003; Jacobs et al., 2011).

In general, meditation, independent of any kind of techniques, provides relaxation, the regulation of attention and thought control (Sperduti, Martinelli \& Piolino, 2012), and decreases the emotional interference to face unpleasant situations (Boccia, Piccardi \& Guariglia, 2015).

Accordingly, meditation could be associated with antidepressant medicine (Kuyken et al., 2008), because it can improve clinical disorders as an amelioration of anxiety (Goldin \& Gross, 2010), depression (Barnhofer et al., 2009; Vøllestad et al., 2012), stress (Carlson et al., 2003) and attention deficit hyperactivity disorder (Krisanaprakornkit et al., 2010) reinforcing the hypothesis of the preventive medicine.

In this way, the practice of meditation could be used for the prevention of mental illness or disturbances such as stresses, dementias in general, depression, anxiety, for instance, or to avoid and/or to slow senile dementia, i.e., could be used an adjuvant in psychiatric treatment.

The objective of this review is to study the effects of meditation on the body and mind and to associate these data with the possibility of using meditation techniques as an alternative medicine method to improve health.

\section{Methodology}

For the purpose of this manuscript, a systematic review methodology was used, considering the indexers meditation, meditation and the brain, meditation and psychiatric disorders and spirituality and psychiatric disorders, totalling 5603 articles from PubMed, 4253 articles from Scopus and 178 results from Scielo for the same indexers. After the verification of the duplicates, there were 352 articles remaining, which were studied and 45 chosen according to their relation to the inclusion criteria. Books and papers about spirituality and about neurological processes were also incorporated. The exclusion criteria were 
papers older than 2000 and papers outside the scope of this manuscript. A total of 57 papers were chosen for the purpose of this study.

\section{Results and Discussion}

To effect this work, 17 articles were studied about meditation and 13 about religiosity after a scrutinising a total of 10034 papers among the descriptors meditation, meditation and the brain, meditation and psychiatric disorders, spirituality and psychiatric disorders.

Accordingly, just the papers pertinent to the objective were considered and they are indicated in Tables 1 and 2. Most of the papers presented experimental designs $(12+7)$ into a various type of meditation and 7 used diagnostic images for meditation papers.

Table 1. Data from papers about meditation used in this article indicating the type of meditation, design and main find.

\begin{tabular}{|c|c|c|c|c|c|}
\hline $\begin{array}{l}\text { Study author } \\
\text { (Year) }\end{array}$ & Sample size & $\begin{array}{l}\text { Type of } \\
\text { meditation }\end{array}$ & Design & Imaging & Study finding \\
\hline Jha (2010) & $\begin{array}{l}\text { Two military } \\
\text { groups during } \\
\text { high stress, one } \\
\text { receiving MT } \\
(\mathrm{n}=31) \text { and one } \\
\text { for control }(\mathrm{n}=17)\end{array}$ & Mindfulness & experimental & no use & $\begin{array}{l}\text { Those who spent little time engaging in MT } \\
\text { exercises (low practice group) saw significant } \\
\text { degradation in their Ospan scores over time, } \\
\text { civilians and military cohort. In contrast, the } \\
\text { high practice group demonstrated modest } \\
\text { improvements over time. Also, with } \\
\text { continuous practice, greater practice time } \\
\text { corresponded to greater WMC at the second } \\
\text { test. }\end{array}$ \\
\hline MacLean (2010) & $\begin{array}{l}\mathrm{n}=60 \text { (retrait } \\
\text { group } \mathrm{n}=30 \\
\text { waiting list group } \\
\mathrm{n}=30\end{array}$ & Shamatha & experimental & no use & $\begin{array}{l}\text { Improvements in visual perception and } \\
\text { vigilance; the results suggest that the training } \\
\text { increased the resources for sustaining } \\
\text { voluntary attention. }\end{array}$ \\
\hline Condon (2013) & $\begin{array}{l}\mathrm{n}=39,29 \text { female, } \\
10 \text { male; } \\
\text { comparison with } \\
\text { waiting-list } \\
\text { control group }\end{array}$ & $\begin{array}{l}\text { two groups, } \\
\text { mindfulness } \\
\text { and } \\
\text { compassion } \\
\text { meditation }\end{array}$ & experimental & no use & $\begin{array}{l}\text { meditation enhanced compassionate } \\
\text { responding in participants of both groups of } \\
\text { meditators in comparison with the waiting- } \\
\text { list control group }\end{array}$ \\
\hline Hölzel (2007) & $\begin{array}{l}\mathrm{n}=30,15 \\
\text { meditators (mean } \\
\text { age: } 33.8 \text { years; } \\
\text { standard deviation } \\
\text { (S.D.): } 4.6 \text { years) } \\
\text { and } 15 \text { non- } \\
\text { meditators (mean } \\
\text { age: } 33.4 \text { years; } \\
\text { S.D.: } 5.6 \text { years). } \\
12 \text { male and } 3 \\
\text { female in each } \\
\text { group }\end{array}$ & Vipassana & experimental & $\begin{array}{l}\text { MRI T2*- } \\
\text { weighted } \\
\text { gradient } \\
\text { echo- } \\
\text { planar } \\
\text { imaging } \\
\text { sequence } \\
\text { (EPI) with } \\
30 \text { axial } \\
\text { slices } \\
\text { covering } \\
\text { the whole } \\
\text { brain }\end{array}$ & $\begin{array}{l}\text { significant brain activation in the rostral ACC } \\
\text { and significantly more activation in the dorsal } \\
\text { MPFC in meditators than non-meditators, } \\
\text { suggesting more activity in processing } \\
\text { emotional conflict and in the cognitive } \\
\text { aspects of emotional processing; also self- } \\
\text { report indicated more attention regulation in } \\
\text { meditators, who experienced less boredom, } \\
\text { sustain more continuous attention during the } \\
\text { tasks and felt more able to complete them }\end{array}$ \\
\hline Larouche (2015) & not applicable & $\begin{array}{l}\text { Mindfulness- } \\
\text { based } \\
\text { interventions }\end{array}$ & review & no use & $\begin{array}{l}17 \text { articles about the effect of MBI on } \\
\text { cortisol, where the most common result was } \\
\text { decreased cortisol level; } 4 \text { studies on the } \\
\text { effects of MBI on cortisol's anti- } \\
\text { inflammatory properties, that showed lower } \\
\text { inflammation and down-regulation of NF-kB; } \\
7 \text { studies on the effects of MBI on pro and } \\
\text { anti-inflammatory cytokines, where the main }\end{array}$ \\
\hline
\end{tabular}




\begin{tabular}{|c|c|c|c|c|c|}
\hline & & & & & $\begin{array}{l}\text { result was a decrease in pro-inflammatory } \\
\text { cytokines and a shift to a more healthy state } \\
\text { in terms of cytokines production; } 3 \text { articles } \\
\text { about the effects of MBI on serotonin, where } \\
\text { two showed increased levels and one showed } \\
\text { decreased levels; } 5 \text { articles about effects of } \\
\text { MBI on telomere function and length, where } \\
\text { the main result was higher telomerase } \\
\text { activity; } 12 \text { articles on the effects of MBI on } \\
\text { oxidation and antioxidants, that showed lower } \\
\text { oxidants levels in most articles, and some } \\
\text { studies also presented higher antioxidants } \\
\text { levels. }\end{array}$ \\
\hline Kang (2013) & $\begin{array}{l}\mathrm{n}=92,46 \\
\text { meditation } \\
\text { practitioners (16 } \\
\text { male and } 30 \\
\text { female) and } 46 \\
\text { control subjects } \\
(17 \text { male and } 29 \\
\text { female) }\end{array}$ & $\begin{array}{l}\text { Brain Wave } \\
\text { Vibration }\end{array}$ & experimental & $\begin{array}{l}\text { MRI with } \\
\text { Diffusion } \\
\text { Tensor } \\
\text { Imaging } \\
\text { (DTI) and } \\
\text { Cortical } \\
\text { Thickness } \\
\text { Analysis }\end{array}$ & $\begin{array}{l}\text { meditators had thicker cortex in the frontal- } \\
\text { temporal region as bilateral ventromedial } \\
\text { PFC, superior frontal cortex and middle and } \\
\text { inferior temporal cortices than controls. } \\
\text { Meditators compared with controls had } \\
\text { thinner cortex in parietal-occipital region, } \\
\text { including bilateral postcentral and inferior } \\
\text { parietal cortices and left PCC. Additionally, } \\
\text { the left superior frontal cortical thickness } \\
\text { adjacent to the primary motor cortex in } \\
\text { meditators showed a positive trend } \\
\text { correlation with the duration of meditation } \\
\text { practice. } \\
\text { DTI results showed higher fractional } \\
\text { anisotropy(FA) values in the anterior } \\
\text { part of the brain in meditators, mainly in the } \\
\text { MPFC; and reduced FA values in some of } \\
\text { MPFC, PCC and the occipital cortex in } \\
\text { meditators compared with controls. }\end{array}$ \\
\hline Goldin (2010) & $\begin{array}{l}\mathrm{n}=16 \text { adult } \\
\text { patients diagnosed } \\
\text { with primary } \\
\text { generalized SAD } \\
\text { according to } \\
\text { DSM-IV ( } 9 \\
\text { female, } 7 \text { male) }\end{array}$ & $\begin{array}{l}\text { Mindfulness- } \\
\text { Based stress } \\
\text { reduction, } \\
\text { including } \\
\text { breath- } \\
\text { focusing } \\
\text { attention and } \\
\text { distraction } \\
\text { focusing } \\
\text { attention (as } \\
\text { control } \\
\text { strategy) }\end{array}$ & experimental & fMRI & $\begin{array}{l}\text { MBSR participants showed improvement in } \\
\text { anxiety and depression symptoms and self- } \\
\text { esteem. During the breath-focused attention } \\
\text { task they also showed decreased negative } \\
\text { emotion experience, reduced amygdala } \\
\text { activity, and increased activity in brain } \\
\text { regions implicated in attentional deployment. } \\
\text { This reduction in negative emotion was not } \\
\text { perceived using distraction-focused attention. }\end{array}$ \\
\hline Barnhofer (2009) & $\begin{array}{l}\mathrm{n}=28,14 \text { received } \\
\mathrm{MBCT} \text { in addition } \\
\text { to usual treatment } \\
\text { and } 14 \text { received } \\
\text { usual treatment } \\
\text { only, for control }\end{array}$ & $\begin{array}{l}\text { Mindfulness- } \\
\text { based } \\
\text { cognitive } \\
\text { therapy }\end{array}$ & experimental & no use & $\begin{array}{l}\text { Greater changes in depressive symptoms in } \\
\text { the MBCT group comparing to control; for } \\
\text { changes in diagnostic status, of those who } \\
\text { had met criteria for MDD, } 70 \% \text { of the MBCT } \\
\text { group did not meet criteria for post- } \\
\text { assessment Major Depression episode, in } \\
\text { contrast with } 18 \% \text { of the control group; for } \\
\text { suicidal tendencies, there were no significant } \\
\text { changes between the two groups }\end{array}$ \\
\hline Carlson (2003) & $\begin{array}{l}\mathrm{n}=59,49 \text { patients } \\
\text { with breast cancer } \\
\text { and } 10 \text { with } \\
\text { prostate cancer }\end{array}$ & $\begin{array}{l}\text { Mindfulness- } \\
\text { based Stress } \\
\text { reduction }\end{array}$ & experimental & $\begin{array}{l}\text { use of } \\
\text { laboratory } \\
\text { exams }\end{array}$ & $\begin{array}{l}\text { Improvements in quality of life, stress and } \\
\text { sleep quality. No significant changes in the } \\
\text { number of lymphocytes; increased T cell } \\
\text { production of IL- } 4 \text { and decreased IFN-gama; } \\
\text { production of IL-10 by NK cells also } \\
\text { decreased. }\end{array}$ \\
\hline
\end{tabular}




\begin{tabular}{|c|c|c|c|c|c|}
\hline $\begin{array}{l}\text { KrisanaprakOrnkit } \\
\text { (2010) }\end{array}$ & not applicable & $\begin{array}{l}\text { Mantra } \\
\text { meditation } \\
\text { and Yoga }\end{array}$ & review & no use & $\begin{array}{l}\text { Four studies in total, all randomized } \\
\text { controlled trials; Two studies about mantra } \\
\text { meditation and two studies about yoga. Only } \\
\text { one study presented appropriate data for } \\
\text { analysis - there was no significant difference } \\
\text { between meditation group and drug group on } \\
\text { teacher rating, also no difference between } \\
\text { meditation group and standard therapy group } \\
\text { on teacher rating nor distraction test. } \\
\text { Limitations on the studies caused high risk of } \\
\text { bias. }\end{array}$ \\
\hline Bostock (2019) & $\mathrm{n}=238$ employees & Mindfulness & experimental & no use & $\begin{array}{l}\text { The intervention group showed improvement } \\
\text { in well-being, distress, job strain, and } \\
\text { perceptions of workplace social support } \\
\text { compared to the control group. The } \\
\text { intervention group also had a significant } \\
\text { decrease in self-measured workday systolic } \\
\text { blood pressure from pre to post intervention, } \\
\text { and were found sustained positive effects for } \\
\text { well-being and job strain at the 16-week } \\
\text { follow-up assessment. }\end{array}$ \\
\hline Kwak (2019) & $\begin{array}{l}\mathrm{n}=37,23 \\
\text { receiving } \\
\text { mindfulness } \\
\text { meditation } \\
\text { training and } 14 \\
\text { going through a } \\
\text { relaxation } \\
\text { program not } \\
\text { related to } \\
\text { meditation } \\
\text { activities }\end{array}$ & $\begin{array}{l}\text { Buddhist } \\
\text { mindfulness }\end{array}$ & experimental & fMRI & $\begin{array}{l}\text { Behavioral differences in the meditation } \\
\text { group after taking the training, specifically } \\
\text { concerning the executive control network. } \\
\text { Imaging results show differences in VOIs of } \\
\text { brain regions associated with conflict } \\
\text { detection and solution (DLPFC and ACC). } \\
\text { Functional imaging also shows differences in } \\
\text { the alerting network (STG and left insula) in } \\
\text { those who took the meditation program in } \\
\text { comparison to those who did not. No } \\
\text { significant behavioral difference was } \\
\text { observed in alerting and orienting networks. } \\
\text { However, the functional imaging shows } \\
\text { significant differences in orienting network } \\
\text { interactions in the meditation group in } \\
\text { contrast to the relaxation group. }\end{array}$ \\
\hline Ionson (2019) & $\begin{array}{l}\mathrm{n}=83,40 \\
\text { receiving Sahaj } \\
\text { Samadhi } \\
\text { Meditation (SSM) } \\
\text { and } 43 \text { in control } \\
\text { group receiving } \\
\text { treatment as usual } \\
\text { (TAU) for } \\
\text { depression }\end{array}$ & $\begin{array}{l}\text { Sahaj } \\
\text { Samadhi } \\
\text { Meditation }\end{array}$ & experimental & no use & $\begin{array}{l}\text { There was no significant difference in heart- } \\
\text { rate variability (HRV) between the two } \\
\text { groups. Nevertheless, there was significant } \\
\text { difference in the Hamilton Rating Scale for } \\
\text { Depression (HRSD) between the two groups }\end{array}$ \\
\hline Gothe (2019) & not applicable & $\begin{array}{l}\text { Yoga-based } \\
\text { meditation }\end{array}$ & review & $\begin{array}{l}\text { fMRI and } \\
\text { MRI }\end{array}$ & $\begin{array}{l}\text { Studies show that there are differences in } \\
\text { gray matter (GM) volume, density and } \\
\text { cortical thickness between long-term Yoga } \\
\text { practitioners and control groups. These } \\
\text { studies also investigated regions such as } \\
\text { hippocampus, which showed greater volume } \\
\text { in comparison to the non-practitioner group, } \\
\text { as well as many other brain regions that had } \\
\text { significant differences between the two } \\
\text { groups. Other studies sought to investigate } \\
\text { short-term effects of Yoga practice in the } \\
\text { brain, with consistent findings of GM volume } \\
\text { changes in certain brain regions, such as }\end{array}$ \\
\hline
\end{tabular}




\begin{tabular}{|c|c|c|c|c|c|}
\hline & & & & & $\begin{array}{l}\text { hippocampus and dorsal anterior cingulate } \\
\text { cortex. The fMRI findings reveal that Yoga } \\
\text { practitioners show different task related brain } \\
\text { activation in comparison to non-practitioners } \\
\text { in different brain areas such as the ones } \\
\text { mentioned above. }\end{array}$ \\
\hline Kober (2019) & $\begin{array}{l}\mathrm{n}=17 \text {, participants } \\
\text { going through } \\
\text { both "react" and } \\
\text { "accept" cycles of } \\
\text { stimuli and } \\
\text { response. When } \\
\text { participants were } \\
\text { told to "react" to a } \\
\text { certain painful or } \\
\text { not stimuli, they } \\
\text { were instructed to } \\
\text { react naturally }\end{array}$ & $\begin{array}{l}\text { Mindfulness } \\
\text { acceptance }\end{array}$ & experimental & $\begin{array}{l}\text { fMRI and } \\
\text { MRI }\end{array}$ & $\begin{array}{l}\text { Participants self reported feeling less negative } \\
\text { affect when exposed to both negative images } \\
\text { and a painful stimuli when instructed to } \\
\text { perform a mindful acceptance as they were } \\
\text { prior instructed to do, whereas participants } \\
\text { reported a higher negative affect when } \\
\text { instructed to react naturally. fMRI shows a } \\
\text { decreased activation on the right amygdala in } \\
\text { response to negative visual and physical } \\
\text { stimuli when participants were instructed to } \\
\text { accept the feeling. Furthermore, brain scans } \\
\text { show a widespread decreased activation of } \\
\text { regions associated with pain processing in } \\
\text { mindfulness acceptance in comparison to } \\
\text { natural reaction. }\end{array}$ \\
\hline $\begin{array}{l}\text { González-Válero } \\
\text { (2019) }\end{array}$ & not applicable & $\begin{array}{l}\text { Mindfulness, } \\
\text { yoga and tai } \\
\text { chi }\end{array}$ & review & no use & $\begin{array}{l}26 \text { articles were selected concerning } \\
\text { treatment of anxiety, } 20 \text { concerning stress } \\
\text { treatment and } 25 \text { concerning interventions for } \\
\text { depression. Short-term interventions showed } \\
\text { almost no effect on reducing mental } \\
\text { disorders, whereas long-term interventions } \\
\text { ( }>9 \text { weeks) resulted in greater positive (mild } \\
\text { to moderate) effects on stress, anxiety and } \\
\text { depression. }\end{array}$ \\
\hline Lutz (2008) & not applicable & $\begin{array}{l}\text { Focused } \\
\text { attention and } \\
\text { open } \\
\text { monitoring }\end{array}$ & review & $\begin{array}{l}\text { fMRI and } \\
\text { MRI }\end{array}$ & $\begin{array}{l}\text { This review conceptualizes focused attention } \\
\text { meditation as the practice of intentionally } \\
\text { dissociating from distractors and sustaining } \\
\text { attention to a particular object, whereas open } \\
\text { monitoring meditation entails the ability of a } \\
\text { non explicit focus on objects while } \\
\text { monitoring sensations, perceptuous and } \\
\text { endogenous stimuli. The review also provides } \\
\text { explanations on neural correlates of cognitive } \\
\text { functions implied in each meditation type, } \\
\text { and subsequent brain structure changes in } \\
\text { expert practitioners. }\end{array}$ \\
\hline Zeidan (2012) & Not applicable & $\begin{array}{l}\text { Mindfulness } \\
\text { meditation }\end{array}$ & Review & $\begin{array}{l}\text { fMRI and } \\
\text { MRI }\end{array}$ & $\begin{array}{l}\text { The work assesses the different factors that } \\
\text { influence the perception of pain, such as } \\
\text { attention, emotional distress, predictive cues, } \\
\text { beliefs and mood. Other studies reveal that } \\
\text { meditation practices modify these factors, } \\
\text { with neuroimaging correlates as supportive } \\
\text { evidence. Studies reveal, indeed, that } \\
\text { meditation is positively correlated to a } \\
\text { reduction in the experience of pain. The } \\
\text { article then reviews neural imaging studies to } \\
\text { provide the neural correlates of meditation } \\
\text { and pain reduction. }\end{array}$ \\
\hline Vøllestad (2012) & Not applicable & $\begin{array}{l}\text { Mindfulness } \\
\text { and } \\
\text { acceptance- } \\
\text { based }\end{array}$ & Review & No use & $\begin{array}{l}\text { This review investigates the role of MABIs in } \\
\text { the mitigation of anxiety and depressive } \\
\text { symptoms. Studies analyzing pre and post } \\
\text { intervention assessment of symptoms reveal } \\
\text { that MABIs yield significant symptomatic }\end{array}$ \\
\hline
\end{tabular}




\begin{tabular}{|c|c|c|c|c|c|}
\hline & & $\begin{array}{l}\text { interventions } \\
\text { (MABI) }\end{array}$ & & & $\begin{array}{l}\text { melioration in participants when compared to } \\
\text { control. }\end{array}$ \\
\hline Sperduti (2012) & Not applicable & $\begin{array}{l}\text { Mindfulness } \\
\text { meditation }\end{array}$ & Review & $\begin{array}{l}\text { fMRI and } \\
\text { MRI }\end{array}$ & $\begin{array}{l}\text { The study considers that regardless of } \\
\text { meditation type, all practices commonly } \\
\text { involve some neural structures related to } \\
\text { relaxation, detachment from one's thoughts } \\
\text { and emotional regulation. They conclude that } \\
\text { the most involved brain areas are the MPFC, } \\
\text { left entorhinal cortex and left caudate body. } \\
\text { Other areas are also more activated in } \\
\text { meditators. All of them are indeed involved } \\
\text { in emotional regulation, relaxation and } \\
\text { thought control. }\end{array}$ \\
\hline Menezes (2015) & $\begin{array}{l}\mathrm{n}=33,19 \text { control } \\
\text { and } 14 \text { subjects to } \\
\text { short Mindfulness } \\
\text { intervention. The } \\
\text { instruments used } \\
\text { were the Positive } \\
\text { Affect and } \\
\text { Negative Affect } \\
\text { Scale, State and } \\
\text { Trait Anxiety } \\
\text { Inventory, and the } \\
\text { Concentrated } \\
\text { Attention Test }\end{array}$ & Mindfulness & experimental & no use & $\begin{array}{l}\text { Results reveal that no significant difference } \\
\text { was observed between the two groups in pre- } \\
\text { intervention tests. Nevertheless, post- } \\
\text { intervention testing reveals statistically } \\
\text { significant decrease in symptoms of anxiety } \\
\text { and depression, and better focused attention, } \\
\text { as evaluated in scores. }\end{array}$ \\
\hline Kuyken (2008) & $\begin{array}{l}\mathrm{n}=123,62 \text { control } \\
\text { patients receiving } \\
\text { anti depressant } \\
\text { medication } \\
\text { (ADM) and } 61 \\
\text { patients receiving } \\
\text { ADM + } \\
\text { Mindfulness } \\
\text { Based Cognitive } \\
\text { Therapy (MBCT }\end{array}$ & MBCT & experimental & no use & $\begin{array}{l}\text { Study reveals that MBCT poses as a positive } \\
\text { intervention relative to preventing depression } \\
\text { relapses and residual depressive symptoms. } \\
\text { Over a } 15 \text {-month follow-up, relapses } \\
\text { occurred only in } 47 \% \text { of MBCT patients } \\
\text { when compared to } 60 \% \text { in the control group. } \\
\text { MBCT was effective in improving quality of } \\
\text { life and diminishing residual depressive } \\
\text { symptoms }\end{array}$ \\
\hline Jacobs (2011) & $\begin{array}{l}\mathrm{n}=60,30 \\
\text { participants } \\
\text { undertaking a } \\
\text { meditation retreat } \\
\text { of } 3 \text { months and } \\
30 \text { control } \\
\text { participants in a } \\
\text { waitlist. Scores } \\
\text { were used to } \\
\text { assess emotional } \\
\text { control and } \\
\text { feelings of } \\
\text { purpose in life. } \\
\text { Blood samples } \\
\text { were collected to } \\
\text { analyze } \\
\text { telomerase } \\
\text { activity in } \\
\text { peripheral cells. }\end{array}$ & Mindfulness & experimental & no use & $\begin{array}{l}\text { Results reveal a significantly greater } \\
\text { telomerase activity in retreat participants than } \\
\text { control. Increased score in Perceived Control } \\
\text { and decreased in Neuroticism in the retreat } \\
\text { group. Mediation analyses pose the neural } \\
\text { mechanisms assessed in Perceived Control } \\
\text { and decreased Neuroticism as responsible for } \\
\text { increased telomerase activity, which is related } \\
\text { to immune cell longevity. }\end{array}$ \\
\hline
\end{tabular}

Source: Authors. 
Table 2. Data from the papers about spirituality.

\begin{tabular}{|c|c|c|c|c|}
\hline $\begin{array}{l}\text { Study author } \\
\text { (Year) }\end{array}$ & Sample size & design & imaging & study finding \\
\hline $\begin{array}{l}\text { Barricelli } \\
(2012)\end{array}$ & $\begin{array}{l}n=60,11 \text { male and } 49 \text { female, age } \\
\text { between } 61 \text { and } 85 \text { years old }\end{array}$ & experimental & no use & $\begin{array}{l}\text { No statistically difference in all the areas of the } \\
\text { Medical Outcomes Study } \\
\text { 36-Item Short-Form Health Survey (SF-36) among } \\
\text { women about intrinsic and extrinsic religiosity. In } \\
\text { the field "General health", men with intrinsic } \\
\text { religion presented a positive difference. }\end{array}$ \\
\hline Byrd (1988) & $\begin{array}{l}\mathrm{n}=393,192 \text { to an intercessory } \\
\text { pray group and } 201 \text { to a control } \\
\text { group }\end{array}$ & experimental & no use & $\begin{array}{l}\text { The intercessory prayer group presented lower } \\
\text { severity outcomes after entry. Ventilatory } \\
\text { assistance, antibiotics and diuretics were less } \\
\text { frequently required in IP group than in patients in } \\
\text { control group. } 85 \% \text { in the prayer group were } \\
\text { considered to have a good hospital course after } \\
\text { entry vs } 73 \% \text { in the control group; } 1 \% \text { of the prayer } \\
\text { group showed intermediate hospital course in } \\
\text { contrast to } 5 \% \text { of the controls, and a bad hospital } \\
\text { course was observed in } 14 \% \text { of the prayer group vs } \\
22 \% \text { of the controls. }\end{array}$ \\
\hline $\begin{array}{l}\text { Comstock } \\
(1972)\end{array}$ & not applicable & review & no use & $\begin{array}{l}\text { To provide basic information about church } \\
\text { attendance the study used a nonofficial census made } \\
\text { in Washington County. The findings showed that } \\
\text { the risk of dying from arteriosclerotic heart disease } \\
\text { was higher to infrenquent church attenders than to } \\
\text { frequent ones, and the death rates for emphysema, } \\
\text { cirrhosis and suicide did not differ between these } \\
\text { two groups. For Catholic males, heavy drinking and } \\
\text { cirrhosis had the same death rates regardless of } \\
\text { frequency of church attendance. }\end{array}$ \\
\hline $\begin{array}{l}\text { Ellison } \\
(1994)\end{array}$ & $\begin{array}{l}\mathrm{n}=2956 \text { from a southeastern } \\
\text { community }\end{array}$ & experimental & no use & $\begin{array}{l}\text { Frequent church attenders report more types of } \\
\text { social support, more social networks, more frequent } \\
\text { social interaction and more positive perceptions of } \\
\text { their relationships quality than those who do not go } \\
\text { to church. }\end{array}$ \\
\hline $\begin{array}{l}\text { Ellison } \\
(1996)\end{array}$ & not applicable & review & no use & $\begin{array}{l}\text { The study used data from the National Survey of } \\
\text { Black Americans to analyze religious coping among } \\
\text { African Americans. Approximately } 80 \% \text { reported } \\
\text { using prayer as a coping resource to confront } \\
\text { serious personal problems, such as praying or } \\
\text { asking someone to pray for. In addition to that, } \\
\text { people that are dealing with a health problem are } \\
\text { more likely to use religion as a coping mechanism } \\
\text { than people with other kinds of problems; women } \\
\text { are more likely to turn to prayer, and the use of } \\
\text { religion coping is unrelated to access to social } \\
\text { network, such as family and friends. }\end{array}$ \\
\hline $\begin{array}{l}\text { Farris } \\
(2011)\end{array}$ & not applicable & review & no use & $\begin{array}{l}\text { The study analyzed religion and religious practice } \\
\text { in the light of psychology and based on studies that } \\
\text { considered religion as part of human behavior. } \\
\text { Among the conclusions: religion is generally } \\
\text { beneficial to mental health and there are some types } \\
\text { of religion that can harm health. Religion has the } \\
\text { potential to have a positive or negative effect on } \\
\text { health, but it is not an expression of mental illness. } \\
\text { The study also discusses Allport's studies, about } \\
\text { intrinsic and extrinsic religion, personality }\end{array}$ \\
\hline
\end{tabular}




\begin{tabular}{|c|c|c|c|c|}
\hline & & & & $\begin{array}{l}\text { construction and mature or immature religious } \\
\text { feeling. }\end{array}$ \\
\hline Fleck (2003) & $\begin{array}{l}\mathrm{n}=142 \text {, divided in } 15 \text { groups } \\
\text { including healthcare } \\
\text { professionals, patients with acute } \\
\text { and chronic disease, terminal } \\
\text { patients, religious people } \\
\text { comprising different kinds of } \\
\text { beliefs. Participants were } \\
\text { submitted to the WHOQOL tool. } \\
\text { The study also describes the } \\
\text { different stages of the WHOQOL } \\
\text { tool's development }\end{array}$ & experimental & no use & $\begin{array}{l}\text { Study found that individuals in each group had a } \\
\text { similar opinion concerning the different subjects } \\
\text { approached by researchers in the WHOQOL tool, } \\
\text { revealing that the focal group technique was } \\
\text { accurate to detect participants' opinions and } \\
\text { demonstrate the hypotheses that were raised, } \\
\text { allowing to modify and/or broaden pre established } \\
\text { concepts. Furthermore, the study reveals the } \\
\text { importance of spirituality in patients' lives, from } \\
\text { their point of view. }\end{array}$ \\
\hline Idler (1987) & $\begin{array}{l}\mathrm{n}=2756,1319 \text { elderly men and } \\
1637 \text { elderly women, interviewed } \\
\text { face-to-face and composing the } \\
\text { database for the study. The study } \\
\text { analyses religious engagement } \\
\text { and two measures of health } \\
\text { status, functional disability and } \\
\text { psychological distress, both } \\
\text { analysis controlling for chronic } \\
\text { diseases (self reported by } \\
\text { patients) }\end{array}$ & experimental & no use & $\begin{array}{l}\text { Study found that for both men and women there is } \\
\text { an inverse association of public religiousness } \\
\text { (attendance to religious service and number of other } \\
\text { congregation members known to the respondent) } \\
\text { and disability. When participants received } \\
\text { explanations on the four hypotheses brought up in } \\
\text { the study, the inverse association had a slight } \\
\text { reduction in the model controlling for chronic } \\
\text { disabilities. This is probably due to the fact that the } \\
\text { disability itself hampers the ability to attend to } \\
\text { religious services and engage in such services. }\end{array}$ \\
\hline $\begin{array}{l}\text { Koenig } \\
(1988)\end{array}$ & $\begin{array}{l}\mathrm{n}=836 \text { older adults divided in } \\
\text { five groups: patients of a } \\
\text { university-affiliated geriatric } \\
\text { outpatient clinic, participants in a } \\
\text { state-sponsored } \\
\text { seniors' lunch program, older } \\
\text { members of a group of } \\
\text { conservative protestant churches, } \\
\text { participants in a } \\
\text { Jewish seniors' lunch program, } \\
\text { and a group of retired Dominican } \\
\text { and Franciscan nuns }\end{array}$ & experimental & no use & $\begin{array}{l}\text { Women were highly more likely than men to score } \\
\text { high in religiosity measures. Inverse correlation } \\
\text { between age and religiosity, and a significant } \\
\text { inverse correlation between age and morale. Social } \\
\text { support was positively correlated with morale, } \\
\text { subjective coping, and organized religious activities } \\
\text { (ORA). Financial status and subjective health } \\
\text { measures were strongly correlated with coping and } \\
\text { morale and were associated with ORA. }\end{array}$ \\
\hline $\begin{array}{l}\text { Levin } \\
(1987)\end{array}$ & not applicable & review & no use & $\begin{array}{l}\text { Studies have been approaching religious factors and } \\
\text { health over the last two centuries. In contrast, there } \\
\text { are still plenty of academic claims suggesting a } \\
\text { scarcity of studies concerning religious factors and } \\
\text { health. Some studies suggest a lower risk of certain } \\
\text { illnesses such as hypertension and some cancers in } \\
\text { those with religious involvement. Studies' results } \\
\text { point to a better health and life quality in people } \\
\text { with religious involvement. }\end{array}$ \\
\hline $\begin{array}{l}\text { Levin, } \\
\text { Vanderpool } \\
(1987)\end{array}$ & not applicable & review & no use & $\begin{array}{l}\text { Studies reveal an association between religious } \\
\text { attendance and health, despite being a weak and } \\
\text { methodologically contestable association that in } \\
\text { fact reveals the need for more research. The authors' } \\
\text { believe that more studies will shed light upon the } \\
\text { raised question and that the answer found will be an } \\
\text { association between religious attendance and health. }\end{array}$ \\
\hline $\begin{array}{l}\text { Medeiros } \\
(2010)\end{array}$ & $\begin{array}{l}\mathrm{n}=90 \text {, participants evaluated by } \\
\text { the WHOQOL-BREF and RAAQ } \\
\text { tools, Guild Multidimensional } \\
\text { Scale and a socio-demographic } \\
\text { and clinical questionnaire. }\end{array}$ & experimental & no use & $\begin{array}{l}\text { Study found that } 87,8 \% \text { of participants had used } \\
\text { antiretroviral therapies and } 60 \% \text { had not been } \\
\text { infected by opportunistic pathogens. A good quality } \\
\text { of life was verified among patients and women } \\
\text { reported a higher degree of satisfaction on the } \\
\text { physical domain than men. There was a positive } \\
\text { association between the }\end{array}$ \\
\hline
\end{tabular}




\begin{tabular}{|c|c|c|c|c|}
\hline & & & & $\begin{array}{l}\text { religiousness/spirituality/personal beliefs (RSPB) } \\
\text { domain and psychological, social and } \\
\text { environmental domains of the WHOQOL-BREF } \\
\text { tool. Women demonstrated higher levels of } \\
\text { religious attitude than men. An inverse correlation } \\
\text { was found between guilt related to time and } \\
\text { physical domain. In symptomatic patients, the same } \\
\text { inverse correlation was found and also included } \\
\text { subjective and objective guilt. The study reveals } \\
\text { that religiousness plays an important role in the } \\
\text { perception of quality of life in those who carry } \\
\text { diseases. Furthermore, the presence of guilt } \\
\text { alongside the clinical progression was evident. }\end{array}$ \\
\hline $\begin{array}{l}\text { Melo } \\
(2015)\end{array}$ & not applicable & review & no use & $\begin{array}{l}\text { The study reveals a relative increase in publications } \\
\text { over time concerning religiousness and quality of } \\
\text { life. The selected studies were separated into } 7 \\
\text { categories: religiousness and spirituality in patients } \\
\text { with chronic diseases; importance of religiousness } \\
\text { for elder people; religiousness and spirituality for } \\
\text { cancer patients; religiousness and spirituality in } \\
\text { HIV patients; relationship between spirituality and } \\
\text { death; religiousness in university students; } \\
\text { relationship between religiousness and depression. } \\
\text { In conclusion, the study found that in fact there is } \\
\text { an association between religiousness and } \\
\text { spirituality and quality of life and coping with } \\
\text { adverse situations. }\end{array}$ \\
\hline $\begin{array}{l}\text { Murakami } \\
(2012)\end{array}$ & not applicable & review & no use & $\begin{array}{l}\text { For this study, after exclusion criteria, } 13 \text { studies } \\
\text { were selected for the review, separated into } 6 \\
\text { categories: religion as a better life quality } \\
\text { contributor dimension, religion as a social support } \\
\text { network, religion as an attributer of meaning to } \\
\text { suffering, relationship between religious } \\
\text { engagement and prevalence of mental illnesses, } \\
\text { religion as a source of mental distress, integration } \\
\text { of religiosity in patient care. The conclusion is that } \\
\text { indeed religion contributes to the treatment of } \\
\text { patients with mental illness, by providing social and } \\
\text { emotional support and teaching a lifestyle coherent } \\
\text { with a better quality of life and health. }\end{array}$ \\
\hline $\begin{array}{l}\text { Stroppa } \\
\text { (2008) }\end{array}$ & Not applicable & review & No use & $\begin{array}{l}\text { This review engages in finding the answer to } \\
\text { whether religiousness and spirituality could be } \\
\text { associated with an improved life quality. The } \\
\text { authors define spirituality and religiousness and } \\
\text { provide a brief history on the relation between } \\
\text { science and religiousness. They conclude the paper } \\
\text { by answering positively the question posed. }\end{array}$ \\
\hline $\begin{array}{l}\text { Rocha } \\
(2011)\end{array}$ & $\begin{array}{l}\mathrm{n}=241 \text {, being } 122 \text { outpatients and } \\
\text { inpatients with some chronic } \\
\text { disease. Study uses WHOQOL- } \\
\text { 100, BDI, WHOQOL-SRPBi. }\end{array}$ & observational & no use & $\begin{array}{l}\text { This study aims to investigate the correlation } \\
\text { between chronic disease and importance attributed } \\
\text { to spirituality, religiousness and personal beliefs } \\
\text { (SRPB). Results demonstrate worse WHOQOL } \\
\text { score of diseased patients when compared to } \\
\text { healthy ones, except in the SRPB domain. Patients } \\
\text { scored higher in the WHOQOL-SRPBi than healthy } \\
\text { controls. Results also reveal a positive correlation } \\
\text { between quality of life, even in chronic disease } \\
\text { patients, with adjusted factors, in those who score } \\
\text { higher in SRPB domains. }\end{array}$ \\
\hline
\end{tabular}




\begin{tabular}{l|l|l|l|l}
\hline $\begin{array}{l}\text { Levin } \\
(2003)\end{array}$ & not applicable & book & no use & $\begin{array}{l}\text { This book aims to investigate the correlation } \\
\text { between quality of life and religious beliefs from } \\
\text { different traditions. Authors make use of different } \\
\text { studies to reveal that there is a positive correlation } \\
\text { between life quality and religiousness. }\end{array}$ \\
\hline $\begin{array}{l}\text { O'regan } \\
(1993)\end{array}$ & not applicable & book & no use & $\begin{array}{l}\text { This book is a bibliography that contains parts of } \\
\text { the major articles about spontaneous remission of } \\
\text { different types of cancer, and its relation with the } \\
\text { mind-body relationship. }\end{array}$ \\
\hline $\begin{array}{l}\text { Angerami- } \\
\text { Camon } \\
(2008)\end{array}$ & not applicable & book & no use & $\begin{array}{l}\text { This book shows thoughts about religions, } \\
\text { psychological theories and Science. }\end{array}$ \\
\hline Paiva (2001) & not applicable & book & no use & $\begin{array}{l}\text { This book asks questions if the religion is a } \\
\text { psychological human need using theoretical- } \\
\text { philosophic digressions. }\end{array}$ \\
\hline
\end{tabular}

Source: Authors.

Studies show changes in brain activity in meditation practitioners, with thicker areas such as the prefrontal medial cortex, orbitofrontal cortex and the frontal superior cortex, and thinner posterior areas (Kang, 2013; Hölzel, 2007; Gothe, 2019).

Meditation practices can bring about changes in the human behavioural reaction to pain perception: experienced meditators show greater tolerances to pain (Zeidan, 2012), as well as a possible tolerance to negative physical and visual stimuli (Kober, 2019), which is also related to changes in brain activity, with less activation of the amygdala (Goldin, 2010), the centre of response to negative stimuli of the brain.

Considering these altered brain regions and behaviour, related to the processing of emotions, decision making and cognition (Hölzel, 2007; Gothe, 2019) which generates, for human physiology, putatively, changes to a less inflammatory state in the body, via modulation of cytokine production (Larouche, 2015), the practice of meditation should be an ally to the treatment of diseases in which pathophysiology involves the brain areas (Ives-Deliperi, 2013; Menezes, 2015; Boccia, 2015).

In this way, meditation proved beneficial in decreasing depressive symptoms and episodes of major depression (Barnhofer, 2009; Goldin, 2010), stress reduction (Carlson, 2003) and also presented a positive relation with decreased anxiety, negative thoughts and improved self-esteem (Goldin, 2010; González-Válero, 2019).

Some subjective effects related to meditation are emotional regulation and disengagement from distractors and repetitive thoughts (Kang, 2013; Boccia, 2015). These effects, taken alone, are themselves related to improvements in symptoms related to psychiatric disorders such as anxiety and depression, conditions that are often associated with difficulties in emotional control and in disengagement from negative thoughts (Dalgalarrondo, 2018; Lutz, 2008; Menezes, 2015).

This became more important for cases of depression refractory to medicines, mainly in considering that studies evaluating the effects of mindfulness-based cognitive therapies (MBCT) reveal that patients who underwent such treatment had fewer relapses or recurrent episodes of depression, with an efficacy comparable to that of medications (Ives-Deliperi, 2013; Chen, 2015). The results of these studies are consistent with fMRI studies revealing that MBCT affects grey matter and the connectivity in several different areas of the pre-frontal cortex, which is the main area affected in mental disorders (Chen, 2015).

In addition, there are positive effects on quality of life and sleep in cancer patients (Carlson, 2003), and it may have positive effects on patients with ADHD and even Alzheimer's (Brewer, 2011).

Although it is still a new area in neuroscience and needs further studies to state more conclusively, the evidence so far suggests a positive correlation of meditation practice with an improvement of the symptoms in diseases such as depression and anxiety mainly, along with an overall positive effect in cognition (Lutz, 2008; Maclean, 2010) and working memory capacity (Jha AP, 2010). 
In this sense, meditation practices are a source of advantages as part of the treatment of anxiety and depression and for other diseases that present these morbidities, at least as an adjuvant therapy.

Mental morbidities are increasing in the world from specific and stochastic factors and, despite the pharmacological evolution in the direction to ameliorate patient conditions, some adverse effects have added to the refractory conditions to medicines. Alternative therapies are used across the world by many classes of population, in some cases without effects or with scarce ones.

\section{Conclusion}

The alternative therapy has demonstrated proven effects, so it must be indicated for patients with medicine problems and for patients in general, and that is the case for meditation practices.

Accordingly, this work shows that meditation practices could be an adjuvant for psychiatric/psychological therapy and should be indicated by the Aesculapius for patients.

Indeed, more studies about meditation with medical objectives could be performed to obtain more data to use this therapy as a psychiatry/psychology adjuvant.

\section{References}

Angerami-Camon, V. A. (compilador)(2008). Psicologia e Religiao. Revista Latinoamericana de Psicología, 40(3), 567-570.

Barnhofer, T., Crane, C., Hargus, E., Amarasinghe, M., Winder, R., \& Williams, J. M. G. (2009). Mindfulness-based cognitive therapy as a treatment for chronic depression: A preliminary study. Behaviour research and therapy, 47(5), 366-373.

Barricelli, I. D. L. F. O., Sakumoto, I. K. Y., Silva, L. H. M. D., \& Araujo, C. V. D. (2012). Influência da orientação religiosa na qualidade de vida de idosos ativos. Revista Brasileira de Geriatria e Gerontologia, 15, 505-515.

Benor, D. (1992). Lessons from spiritual healing research \& practice. Subtle Energies \& Energy Medicine Journal Archives, 3(1).

Boccia, M., Piccardi, L., \& Guariglia, P. (2015). The meditative mind: a comprehensive meta-analysis of MRI studies. BioMed research international, 2015.

Bostock, S., Crosswell, A. D., Prather, A. A., \& Steptoe, A. (2019). Mindfulness on-the-go: Effects of a mindfulness meditation app on work stress and wellbeing. Journal of occupational health psychology, 24(1), 127.

Bowker, J., \& Bowker, J. W. (1975). Problems of Suffering in Religions of the World. Cambridge University Press.

Brewer, J. A., Worhunsky, P. D., Gray, J. R., Tang, Y. Y., Weber, J., \& Kober, H. (2011). Meditation experience is associated with differences in default mode network activity and connectivity. Proceedings of the National Academy of Sciences, 108(50), 20254-20259.

Byrd, R. C. (1988). Positive therapeutic effects of intercessory prayer in a coronary care unit population.

Carlson, L. E., Speca, M., Patel, K. D., \& Goodey, E. (2003). Mindfulness-based stress reduction in relation to quality of life, mood, symptoms of stress, and immune parameters in breast and prostate cancer outpatients. Psychosomatic medicine, 65(4), 571-581.

Chen, F., Lv, X., Fang, J., Yu, S., Sui, J., Fan, L., \& Jiang, T. (2015). The effect of body-mind relaxation meditation induction on major depressive disorder: A resting-state fMRI study. Journal of affective disorders, 183, 75-82.

Comstock, G. W., \& Partridge, K. B. (1972). Church attendance and health. Journal of chronic diseases, 25(12), 665-672.

Condon, P., Desbordes, G., Miller, W. B., \& DeSteno, D. (2013). Meditation increases compassionate responses to suffering. Psychological science, 24(10), 2125-2127.

Dalgalarrondo, P. (2018). Psicopatologia e semiologia dos transtornos mentais. Artmed Editora.

Davidson, R. J., Kabat-Zinn, J., Schumacher, J., Rosenkranz, M., Muller, D., Santorelli, S. F., \& Sheridan, J. F. (2003). Alterations in brain and immune function produced by mindfulness meditation. Psychosomatic medicine, 65(4), 564-570.

de Freitas Melo, C., Sampaio, I. S., de Abreu Souza, D. L., \& dos Santos Pinto, N. (2015). Correlação entre religiosidade, espiritualidade e qualidade de vida: uma revisão de literatura. Estudos e Pesquisas em Psicologia, 15(2), 447-464.

Ellison, C. G., \& George, L. K. (1994). Religious involvement, social ties, and social support in a southeastern community. Journal for the scientific study of religion, 46-61.

Ellison, C. G., \& Taylor, R. J. (1996). Turning to prayer: Social and situational antecedents of religious coping among African Americans. Review of Religious Research, 111-131. 
Farris, J. R., \& Sathler-Rosa, R. (2011). Religião salugênica e religião patogênica: uma aproximação à luz da psicologia. Revista Pistis Praxis, 3(2), 361-382.

Fleck, M. P. D. A., Borges, Z. N., Bolognesi, G., \& Rocha, N. S. D. (2003). Desenvolvimento do WHOQOL, módulo espiritualidade, religiosidade e crenças pessoais. Revista de Saúde Pública, 37, 446-455.

Fox, K. C., Nijeboer, S., Dixon, M. L., Floman, J. L., Ellamil, M., Rumak, S. P., \& Christoff, K. (2014). Is meditation associated with altered brain structure? A systematic review and meta-analysis of morphometric neuroimaging in meditation practitioners. Neuroscience \& Biobehavioral Reviews, 43, 48-73.

Funderburk, J. O. (1977). Science studies yoga: A review of physiological data. Himalayan International Institute of Yoga Science \& Philosophy of USA.

Goldin, P. R., \& Gross, J. J. (2010). Effects of mindfulness-based stress reduction (MBSR) on emotion regulation in social anxiety disorder. Emotion, 10(1), 83.

Gothe, N. P., Khan, I., Hayes, J., Erlenbach, E., \& Damoiseaux, J. S. (2019). Yoga effects on brain health: a systematic review of the current literature. Brain Plasticity, 5(1), 105-122.

González-Valero, G., Zurita-Ortega, F., Ubago-Jiménez, J. L., \& Puertas-Molero, P. (2019). Use of meditation and cognitive behavioral therapies for the treatment of stress, depression and anxiety in students. A systematic review and meta-analysis. International journal of environmental research and public health, 16(22), 4394 .

Grant, J. A., \& Rainville, P. (2009). Pain sensitivity and analgesic effects of mindful states in Zen meditators: a cross-sectional study. Psychosomatic medicine, 71(1), 106-114.

Hölzel, B. K., Ott, U., Hempel, H., Hackl, A., Wolf, K., Stark, R., \& Vaitl, D. (2007). Differential engagement of anterior cingulate and adjacent medial frontal cortex in adept meditators and non-meditators. Neuroscience letters, 421(1), 16-21.

Idler, E. L. (1987). Religious involvement and the health of the elderly: Some hypotheses and an initial test. Social Forces, 66(1), 226-238.

Ionson, E., Limbachia, J., Rej, S., Puka, K., Newman, R. I., Wetmore, S., \& Vasudev, A. (2019). Effects of Sahaj Samadhi meditation on heart rate variability and depressive symptoms in patients with late-life depression. The British Journal of Psychiatry, 214(4), 218-224.

Ives-Deliperi, V. L., Howells, F., Stein, D. J., Meintjes, E. M., \& Horn, N. (2013). The effects of mindfulness-based cognitive therapy in patients with bipolar disorder: a controlled functional MRI investigation. Journal of affective disorders, 150(3), 1152-1157.

Jacobs, T. L., Epel, E. S., Lin, J., Blackburn, E. H., Wolkowitz, O. M., Bridwell, D. A., ... \& Saron, C. D. (2011). Intensive meditation training, immune cell telomerase activity, and psychological mediators. Psychoneuroendocrinology, 36(5), 664-681.

Jha, A. P., Stanley, E. A., Kiyonaga, A., Wong, L., \& Gelfand, L. (2010). Examining the protective effects of mindfulness training on working memory capacity and affective experience. Emotion, 10(1), 54.

Kang, D. H., Jo, H. J., Jung, W. H., Kim, S. H., Jung, Y. H., Choi, C. H., \& Kwon, J. S. (2013). The effect of meditation on brain structure: cortical thickness mapping and diffusion tensor imaging. Social cognitive and affective neuroscience, 8(1), 27-33.

Kober, H., Buhle, J., Weber, J., Ochsner, K. N., \& Wager, T. D. (2019). Let it be: mindful acceptance down-regulates pain and negative emotion. Social cognitive and affective neuroscience, 14(11), 1147-1158.

Koenig, H. G., Kvale, J. N., \& Ferrel, C. (1988). Religion and well-being in later life. The gerontologist, 28(1), 18-28.

Krisanaprakornkit, T., Ngamjarus, C., Witoonchart, C., \& Piyavhatkul, N. (2010). Meditation therapies for attention-deficit/hyperactivity disorder (ADHD). Cochrane Database of Systematic Reviews, (6).

Kuyken, W., Byford, S., Taylor, R. S., Watkins, E., Holden, E., White, K., \& Teasdale, J. D. (2008). Mindfulness-based cognitive therapy to prevent relapse in recurrent depression. Journal of consulting and clinical psychology, 76(6), 966.

Kwak, S., Lee, T. Y., Jung, W. H., Hur, J. W., Bae, D., Hwang, W. J., ... \& Kwon, J. S. (2019). The immediate and sustained positive effects of meditation on resilience are mediated by changes in the resting brain. Frontiers in human neuroscience, 13, 101.

Larouche, E., Hudon, C., \& Goulet, S. (2015). Potential benefits of mindfulness-based interventions in mild cognitive impairment and Alzheimer's disease: an interdisciplinary perspective. Behavioural brain research, 276, 199-212.

Levin, J. (2003). Deus, fé e saúde. Editora Cultrix.

Levin, J. S., \& Schiller, P. L. (1987). Is there a religious factor in health? Journal of Religion and Health, 26(1), 9-36.

Levin, J. S., \& Vanderpool, H. Y. (1987). Is frequent religious attendance really conducive to better health?: Toward an epidemiology of religion. Social Science \& Medicine, 24(7), 589-600.

Lutz, A., Slagter, H. A., Dunne, J. D., \& Davidson, R. J. (2008). Attention regulation and monitoring in meditation. Trends in cognitive sciences, 12(4), 163169.

MacLean, K. A., Ferrer, E., Aichele, S. R., Bridwell, D. A., Zanesco, A. P., Jacobs, T. L., \& Saron, C. D. (2010). Intensive meditation training improves perceptual discrimination and sustained attention. Psychological science, 21(6), 829-839.

Medeiros, B. (2010). A relação entre religiosidade, culpa e avaliação de qualidade de vida no contexto do HIV/AIDS. 
Research, Society and Development, v. 10, n. 9, e26810917929, 2021

(CC BY 4.0) | ISSN 2525-3409 | DOI: http://dx.doi.org/10.33448/rsd-v10i9.17929

Menezes, C. B., \& Bizarro, L. (2015). Effects of a brief meditation training on negative affect, trait anxiety and concentrated attention. Paidéia (Ribeirão Preto), 25, 393-401.

Murakami, R., \& Campos, C. J. G. (2012). Religião e saúde mental: desafio de integrar a religiosidade ao cuidado com o paciente. Revista Brasileira de Enfermagem, 65, 361-367.

O’Regan, B., \& Hirshberg, C. (1993). Spontaneous remission. An Annotated Bibliography. Sausolito: Institute of Noetic Sciences.

Rocha, N. S. D., \& Fleck, M. P. D. A. (2011). Avaliação de qualidade de vida e importância dada a espiritualidade/religiosidade/crenças pessoais (SRPB) em adultos com e sem problemas crônicos de saúde. Archives of Clinical Psychiatry (São Paulo), 38, 19-23.

Sperduti, M., Martinelli, P., \& Piolino, P. (2012). A neurocognitive model of meditation based on activation likelihood estimation (ALE) metaanalysis. Consciousness and cognition, 21(1), 269-276.

Stroppa, A., \& Moreira-Almeida, A. (2008). Religiosidade e saúde. Saúde e espiritualidade: uma nova visão da medicina. Inede, 427-443.

Paiva, G. J. de. (2001). Entre necessidade e desejo: diálogos da psicologia com a religião. Loyola.

Vøllestad, J., Nielsen, M. B., \& Nielsen, G. H. (2012). Mindfulness-and acceptance-based interventions for anxiety disorders: A systematic review and metaanalysis. British journal of clinical psychology, 51(3), 239-260.

Zeidan, F., Grant, J. A., Brown, C. A., McHaffie, J. G., \& Coghill, R. C. (2012). Mindfulness meditation-related pain relief: evidence for unique brain mechanisms in the regulation of pain. Neuroscience letters, 520(2), 165-173. 